\title{
Urban Assertiveness, Legal Frameworks, Informal Networks and Intercity Trade among the Cities of SADC
}

\author{
Marius Pieterse \\ Professor of Law \\ University of Witwatersrand, Johannesburg \\ Marius.Pieterse@wits.ac.za
}

While both international trade law and regional trade agreements in the SADC region are typically focused on nation states, it is cities that produce the bulk of economic goods and services in the region and that, in effect, are the main actors in terms of trade agreements. Similarly, regional trade is facilitated by inter-city infrastructure, connectivity, transport routes and so forth. Indeed, both formal and informal trade in the region predominantly take place on an inter-city level, yet this is seldom perceived or structured by applicable legal regimes. Changes in the legal and/or regulatory landscape in one city may thus have regional trade implications across the region, without these visibly triggering international or regional trade laws or agreements.

One example of this is the City of Johannesburg's ill-fated crackdown on unlicensed informal trade through the so-called "Operation Clean Sweep" in late 2013. Apart from its devastating impact on the lives of Johannesburg-based traders and their families, Operation Clean Sweep's economic effects were felt in cities across SADC and beyond, as a number of formal and informal cross-border trade links were negatively impacted, or even severed, by its implementation.

This paper aims to better understand the role of cities and local government in regional trade, while at the same time exploring the international dimensions of informal trade.

Research for this paper was funded by the Swiss State Secretariat for Economic Affairs under the SECO / WTI Academic Cooperation Project, based at the World Trade Institute of the University of Bern, Switzerland.

SECO working papers are preliminary documents posted on the WTI website (www.wti.org) and widely circulated to stimulate discussion and critical comment. These papers have not been formally edited. Citations should refer to a "SECO / WTI Academic Cooperation Project" paper with appropriate reference made to the author(s).

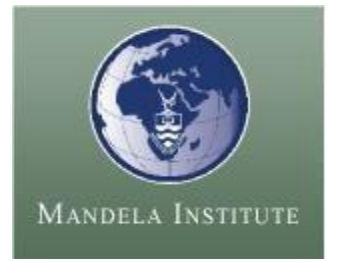




\section{Urban Assertiveness, Legal Frameworks, Informal Networks and Intercity Trade among the Cities of SADC}

\section{Marius Pieterse*}

\section{INTRODUCTION}

One of the most significant by-products of globalisation has been a rather remarkable increase in the social, economic, cultural, financial and political clout of cities and, concomitantly, of local government. In realms of international relations, trade, investment, environmentalism, security and everyday governance, the social and political significance of the decisions and actions of city-governments has grown to the point where it often matches or outstrips that of national or regional governments. At the same time, the increased global connectedness of the information age has enabled intercity networks and flows that have powerfully shaped the global economy. ${ }^{1}$

When it comes to commerce, cities have always been the epicentres of production, manufacturing and trade, much as international trade and investment law have, somewhat paradoxically, always operated near-exclusively at the level of the nation state. As Saskia Sassen shows, economic globalisation has however served to reposition cities, vis a vis nation states, in two important ways: First, there has been increased awareness of the importance of urban productiveness for macroeconomic performance - cities are quite literally the spaces where the overwhelming bulk of goods, services and knowledge of the global economy are

\footnotetext{
* Professor of Law, University of the Witwatersrand, Johannesburg, South Africa. Marius.Pieterse@wits.ac.za. This working paper forms part of an overarching research project looking at various aspects of urban assertiveness and governance in the major cities of the SADC region in sub-Saharan Africa. The desk-work for this paper was conducted during a research exchange visit at the World Trade Institute (WTI) in Bern, Switzerland from 24 November until 14 December 2017, enabled through the Swiss Secretariat for Economic Cooperation (SECO)/WTI Academic Cooperation Program in conjunction with the Mandela Institute in the School of Law at the University of the Witwatersrand. A rudimentary version of this paper was presented at a brownbag seminar at the WTI on 4 December 2017. I am grateful to Rodrigo Polanco, Clarence Siziba, Alexander Beyleveld, Elisa Fornalé and other participants at the seminar for their substantive input and suggestions. This working paper presents an early snapshot of work in progress, with the bulk of the comparative legal study envisioned in sections 2, 3 and 4 to be conducted in 2018.

${ }^{1}$ This is comprehensively traced, for instance, in works such as Benjamin R Barber If Mayors Ruled the World: Dysfunctional Nations, Rising Cities (Yale UP, 2013); Tassilo Herrschel \& Peter Newman Cities as International Actors: Urban and Regional Governance Beyond the Nation State (Palgrave Macmillan, 2017); Saskia Sassen Cities in a World Economy (Sage, 4ed 2012).
} 
produced. Secondly, autonomous and competitive actions in global markets by urban governments and urban-based private sector interest groups, aimed for instance at attracting investment, firms, tourism and major events are now routinely observed - cities are realising their own commercial importance and agency, and are deliberately acting in ways aimed at maximizing these. ${ }^{2}$ Accordingly, it is increasingly acknowledged, also in the legal literature, that the laws, policies and actions of urban local governments can and do operate to bolster or restrict trade, investment and other forms of economic activity. ${ }^{3}$

Indeed, there is a burgeoning, multi-disciplinary literature on the characteristics and actions of so-called 'global cities', the large metropolises that drive the global economy and that accordingly attract the most capital, investment, firms, highly skilled labourers, tourists and so on. For Sassen, global cities are characterised by being '(1) command points in the organization of the world economy, (2) key locations and marketplaces for the leading industries of the current period - finance and specialized services for firms, and (3) major sites of production, including the production of innovations.... 4

All cities are increasingly depicted as competing (or having to compete) for 'global city' status, or superior positions in global city hierarchies, which is commonly associated with being the location of global or regional headquarters of specialized service firms, physical sites for direct capital investment, nodes of global financial flows, ports of global trade, centres of knowledge-generation and preferred residential location of highly skilled individuals. ${ }^{5}$ This competition involves the

\footnotetext{
${ }^{2}$ Sassen op cit note 1 at 12-13. See also, for instance, Barber op cit note 1 at 55; 65; Francois Gipouloux 'From entrepots to service integrators: Asian metropolises in a changing flows and nodes configuration' in Francois Gipouloux (ed) Gateways to Globalisation: Asia's International Trading and Finance Centres (Edward Elgar Publishing, 2011) 1 at 1-3; Edward J Malecki 'Cities and regions competing in the global economy: Knowledge and local development processes' (2007) 25 Environment \& Planning C: Government \& Policy 638-654; Victor Udemezue Onyebueke 'Place and function of African cities in the global urban network: Exploring the matters arising' (2011) 22(1) Urban Forum 1 at 2; 4-7; Richard C Schragger 'Cities, economic development, and the free trade constitution' (2008) 94(5) Virginia Law Review 1091 at 1094-1096; Ana Teresa Tavares-Lehmann \& Rodrigo Tavares 'Economic nationalism is on the rise, but the future of trade lies with cities' World Economic Forum (3 February 2017) available through www.weforum.org; Ivan Turok 'Cities, regions and competitiveness' (2004) 38(9) Regional Studies 1069 at 1070-1076; Willem van Vliet 'Cities in a globalizing world: From engines of growth to agents of change' (2002) 14(1) Environment \& Urbanization 31 at 33; 36-38.

${ }^{3}$ Schragger op cit note 2 at 1096; 1107-1109; 1114-1120. See also Alan Collins 'Making truly competitive cities - on the appropriate role for local government' Economic Affairs (1 September 2007) 75-80; Turok op cit note 2 at 1071.

${ }^{4}$ Sassen op cit note 1 at 7 .

${ }^{5}$ For elaboration on the characteristics of global cities from the perspective of the global South see,
} 
enhancement of cities' physical urban environment, their physical, financial and virtual infrastructure networks, their governance structures, property rights- and taxation regimes, and so forth, all ostensibly geared towards being more businessconducive, economically dense, connected, and 'liveable'. 6 But, in addition to competing, the dynamics of transnational economic globalisation mean that, much like the firms within them, 'global cities' also by necessity interact and cooperate as cities, thereby emerging as independent socio-political and economic actors of constitutional significance. ${ }^{7}$ Indeed, leading 'global cities' (such as London, Paris, New York, and Tokyo) are sometimes said to have more interests in common with each other than with the nation states in which they are situated, and primarily govern and conduct their economic affairs in the interests of (their position in) the global economic order rather than in accordance with national economic policy objectives. $^{8}$

The notion of 'global cities' and its attendant literature have been subject to significant criticism, for underplaying the many functions and activities in cities which do not relate to their positioning in global markets, for side-lining crucial urban governance objectives (relating, for instance, to urban inclusiveness and resilience) and, pertinently, for reflecting a distinct Western, 'first world' bias which simultaneously overlooks and excludes the cities of the developing world, while forcing them to enter a competition which they cannot win. ${ }^{9}$ Indeed, the cities of the developing world are hamstrung in competing for the spoils of the global economy by massive poverty, inequality, underdevelopment and attendant socio-economic challenges, ${ }^{10}$ and it is often argued that meeting these challenges, rather than

for instance, Onyebueke op cit note 2 at 3-6; Udesh Pillay "Are globally competitive "city regions" developing in South Africa? Formulaic aspirations or new imaginations?' (2004) 15(4) Urban Forum 340 at 342; Izak J van der Merwe 'The global cities of sub-Saharan Africa: Fact or fiction?' (2004) 15(1) Urban Forum 36 at 37-39; 43.

${ }^{6}$ See, for instance, Charlotte Lemanski 'Global cities in the South: Deepening social and spatial polarisation in Cape Town' (2007) 24(6) Cities 448 at 448-449; Pillay op cit note 5 at 345-346; Turok op cit note 2 at 1071-1075.

${ }^{7}$ See Barber op cit note 1 at $5 ; 12 ; 163-166$; Sassen op cit note 1 at $7 ; 83 ; 113$.

${ }^{8}$ This is not to say that these cities are similar or act similarly but to suggest that what they have in common is that, as economic agents, they act divergently or independently from nation states in similar ways and in pursuit of similar goals. On some of the intricacies of this see Saskia Sassen The Global City: New York, Tokyo, London (Princeton University Press, 2ed 2001) at 346-355.

${ }^{9}$ See Gipouloux op cit note 2 at 3; Lemanski op cit note 6 at 449-451; Susan Parnell \& Jenny Robinson 'Development and urban policy: Johannesburg's city development strategy' (2006) 43(2) Urban Studies 337 at 339; Pillay op cit note 5 at 343; Turok op cit note 2 at 1072.

${ }_{10}$ See Ambe J Njoh 'African cities and regional trade in historical perspective: Implications for contemporary globalization trends' (2006) 23(1) Cities 18 at 25-26; Onyebueke op cit note 2 at 6; Pillay op cit note 5 at 345-347; Van der Merwe op cit note 5 at 38-40. 
seemingly doomed attempts at competing for 'global city' status, should be the priority for urban governments in the global South. ${ }^{11}$

Yet, far from their typical depiction as being relegated to function as the unidimensional mines, gravel pits and sweat shops for the developed world, cities of the South do engage the global economy, and some are emerging as powerful, even indispensable, players in 'global city' networks. ${ }^{12}$ It is further misleading to pretend that the socio-economic problems plaguing them are not also present in first world cities, as this obscures economic globalisation's propensity to deepen inequality and attendant social polarisation everywhere across the world, ${ }^{13}$ and its simultaneous tendency to generate not only the high-end economic activities alluded to above but also numerous complex low-end flows of labour, goods and capital. ${ }^{14}$ Indeed, a focus on the 'global' cities of the global South reveals a far more intricate picture of the balances and interactions between economic and social urban governance objectives everywhere, ${ }^{15}$ as well as of complex interdependencies between survivalist and profit-driven, formal and informal urban economic activity at different scales.

In this working paper, I begin to consider the powers, functions and actions of urban local governments in the Southern African Development Community (SADC) region of sub-Saharan Africa, in relation to formal and informal cross-border trade. My aim is to better understand the international, legal and constitutional role of urban local government in relation to cities' economic functions, as well as to consider the legal and policy priorities of African cities in the simultaneous quest for economic growth and social upliftment. With my research still in its infancy, this working paper focuses on familiarising the reader with the economic objectives of the SADC as well as with economic conditions and activities in its most significant cities, and on providing a cursory outline of the economic and trade-related powers and functions of, and interactions between, urban local governments in the region. Examples in this working paper are mostly drawn from South African cities, with which I am most

\footnotetext{
${ }^{11}$ See for example Lemanski op cit note 6 at 449 .

${ }^{12}$ See, for instance, Lemanski op cit note 6 at 449; Sassen op cit note 1 at 17; 66; Van der Merwe op cit note 5 at 43 .

${ }^{13}$ Lemanski op cit note 6 at $450 ; 455-456 ; 459$.

${ }_{15}^{14}$ Sassen op cit note 1 at $11-12 ; 89$; 273-296; 326-327.

15 See Jennifer Houghton 'Negotiating the global and the local: Evaluating development through public-private partnerships in Durban, South Africa' (2011) 22(1) Urban Forum 75 at 75-76; Lemanski op cit note 6 at 459; Parnell \& Robinson op cit note 9 at 338; 341; 348; Van Vliet op cit note 2 at 38.
} 
familiar. My intention is to significantly elaborate these, following on a detailed comparative legal study of devolution of state power across the region, which is to be conducted during 2018. Here, I present a cursory overview of formal trade in the region and attempt to situate cities within this nation-state focused narrative, before presenting a case study of informal cross-border trade in the city of Johannesburg as indicative of a far larger, multinational and city-driven economic phenomenon. I proceed to make tentative conclusions on the trade-related powers and inclinations of globally significant city governments in SADC, as well as on their economic policy priorities going forward.

\section{International Trade, the SADC and its Global(ISInG) Cities}

The acronym SADC commonly refers both to the Gaborone-headquartered intergovernmental organisation established to promote economic integration and cooperation among its sixteen member states in southern sub-Saharan Africa and the adjacent Indian Ocean, and to the territorial region covered by these states. ${ }^{16}$ While the SADC member states have different colonial histories, legal systems and developmental trajectories, they face common socio-economic and developmental challenges, including widespread poverty, deepening inequality, underdevelopment, generally low levels of economic productivity and poor integration into global trade networks. The SADC (as an organisation) purports to overcome these obstacles through greater cross-border cooperation and economic integration, improved governance and regional development and ultimately envisions, inter alia, a common SADC market and free movement of people across the region. ${ }^{17}$ In pursuit of these and related goals, the SADC has adopted several binding protocols and strategic instruments, notably the Protocol on Trade (1996), the Protocol on Finance and Investment (2006) and the Regional Infrastructure Development Master Plan (2012). ${ }^{18}$ All these documents and the enforcement mechanisms that they establish operate predominantly or exclusively at the level of the nation state, though the

\footnotetext{
${ }^{16}$ The SADC member states are: South Africa, Lesotho, Swaziland, Namibia, Botswana, Zimbabwe, Mozambique, Angola, Zambia, Malawi, Tanzania, the Democratic Republic of the Congo (DRC), Madagascar, Mauritius, the Seychelles and the Comoros.

${ }_{10}^{17}$ See SADC Regional Indicative Strategic Development Plan (2001) 4-5.

18 Other relevant documents include the Protocol on Facilitation of Movement of Persons (1997, revised 2005); the Protocol on Employment and Labour (2014); the Regional Migration Labour Policy (2014) and the Labour Migration Action Plan (2016).
} 
Regional Infrastructure Development Master Plan does also emphasise crucial urban infrastructure such as ports, railways and airports.

Major cross-border infrastructure projects (such as the Maputo Development Corridor transport infrastructure upgrades between Johannesburg and Maputo, and the transport and port infrastructure upgrades associated with the Walvis Bay SADC Port Development) have boosted economic activity in the region ${ }^{19}$ and a regional free trade zone was established in 2008, though progress towards other strategic goals, including the establishment of a regional customs union, a common market and a common currency is lagging significantly behind the targets laid down in the SADC 2001 Regional Indicative Strategic Development Plan. ${ }^{20}$

GDP growth and export trade from the region has markedly increased over the last 2 decades, though remains low by global standards, ${ }^{21}$ while intra-region trade remains 'weak' and productivity levels remain 'disconcertingly' low. ${ }^{22}$ Economic development and export trade in the region remains profoundly shaped by the remnants of colonialism, with the national and urban economies in the region, and their supporting physical infrastructure, having been 'designed' simply to extract and supply natural (especially mineral) resources to Europe. ${ }^{23}$ Natural and mineral resources continue to dominate export trade, and economic diversification has proved challenging across the board. Meanwhile, intra-region trade and commerce is heavily dominated by South Africa, with many of its neighbouring countries heavily dependent on it for imports, and South African retail firms having aggressively expanded across the region from the mid-1990s onwards. ${ }^{24}$

\footnotetext{
${ }^{19}$ On the Maputo Corridor Project, see for instance S Peberdy \& J Crush 'Invisible trade, invisible travellers: The Maputo Development Corridor Spatial Development Initiative and informal crossborder trading' (2001) 83(2) South African Geographical Journal 115 at 115-116. On the Walvis Bay SADC Port project, see Christopher J Savage, Logan Fransman, Andrew K Jenkins \& Colin G Bramford 'Developing Walvis Bay into a logistics gateway for southern Africa: Issues, challenges and the potential implications for Namibia's future' (2014) 8(1) Journal of Transport and Supply Chain Management 1-10.

20 See Tapiwa Shumba Harmonising Regional Trade Law in the Southern African Development Community (SADC) (Nomos, 2015) at 121.

${ }^{21}$ See Anna Mazzolini 'The rising "floating class" in sub-Saharan Africa and its impact on local governance: Insights from Mozambique' in Carlos Nunes Silva (ed) Governing Urban Africa (Palgrave MacMillan, 2016) 213 at 217-218; Pillay op cit note 5 at 345-346; Shumba op cit note 20 at 117.

${ }^{22}$ Shumba op cit note 20 at $117-118 ; 138$.

${ }^{23}$ See Njoh op cit note 10 at 22-25; van der Merwe op cit note 5 at 40.

${ }^{24}$ See Darlene Miller, Etienne Nel \& Godfrey Hampwaye 'Malls in Zambia: Racialised retail expansion and South African foreign investors in Zambia' (2008) 12(1) African Sociological Review 35-54; Sally Peberdy 'Mobile entrepreneurship: Informal sector cross-border trade and street trade in South Africa' (2000) 17(2) Development Southern Africa 201 at 202-204; Savage et al op cit note 19 at 2; Shumba op cit note 20 at 119 .
} 
Overall, despite significant progress towards economic integration and increased intra- and extra-region trade, formal international trade in and among the countries in SADC trade remains hampered by complex, outdated and poorly integrated legal regimes, 'thick borders' and convoluted customs procedures, tardy logistics networks, high immigration costs and delays and deficient infrastructure. ${ }^{25}$

Notably, such formal economic growth as has occurred in the SADC region has near exclusively taken place in its cities. ${ }^{26}$ Indeed, while they remain relatively poorly integrated into the global economy, especially since its shift away from flows of raw materials, agricultural products and minerals to flows of finance specialist services and innovations, ${ }^{27}$ 'African cities are increasingly the commercial powerhouses for their respective countries'. ${ }^{28}$ Whereas their economies remain dominated by raw material exports, are often dominated by the informal sector and often focus more on servicing surrounding rural areas and on being self-sustaining than on fostering global connections and flows, ${ }^{29}$ increasing numbers of cities in Africa, and SADC in particular, are displaying sufficient 'global city' traits to be recognised as global economic players.

The 2016 issue of the Globalization and World Cities Study Group (GAWC)'s highly-regarded ranking of global cities, based on office networks of producer services firms, ${ }^{30}$ contains 16 cities from the SADC region at levels above 'sufficient' world city presence. Johannesburg in South Africa is the region's only alpha-rated major global city, with a rating revealing levels of global connectedness comparable to first world cities such as Sydney, Chicago, Amsterdam and Milan. ${ }^{31}$ Cape Town is

\footnotetext{
${ }^{25}$ See Colin Fish, Chris Adendorf \& Kobus Jonker 'An investigation into factors impacting on exports from South Africa to the Southern African Development Community (SADC)' (2014) 18(1) African Sociological Review 127 at 131; 137; Njoh op cit note 10 at 24-28; Peberdy op cit note 24 at 215-217; Shumba op cit note 20 at 122; 127-134.

${ }^{26}$ Mazzolini op cit note 21 at 218.

${ }^{27}$ Sassen op cit note 1 at 17 . See also Onyebueke op cit note 2 at $6 ; 18$; Pillay op cit note 5 at 346; van der Merwe op cit note 5 at 38-40.

${ }^{28}$ Sassen op cit note 1 at 66.

${ }^{29}$ See for instance Pillay op cit note 5 at 345-346; Lochner Marais, Deirdre van Rooyen, Molefi Lenka \& Jan Cloete 'Planning for economic development in a secondary city? Trends, pitfalls and alternatives for Mangaung, South Africa' (2014) 26 Bulletin of Geopgraphy, Socio-economic Series 203 at 204-205; Mfaniseni Fana Sihlongonyane 'Local economic development in Swaziland: The case of Manzini city' (2003) 14(2-3) Urban Forum 244 at 244; 257.

30 Available at http://www.lboro.ac.uk/gawc/world2016.html. On GAWC's methodology and the significance of its rankings and classifications, see PJ Taylor 'Specification of the World City Network' (2001) 33(2) Geographical Analysis 181-194, also Onyebueke op cit note 2 at 7-10; van der Merwe op cit note 5 at 37-38; 43.

${ }^{31}$ On Johannesburg economic dominance in the SADC region and its 'global city' status, see Lemanski op cit note 6 at 449; Onyebueke op cit note 2 at 7; Pillay op cit note 5 at 353-355.
} 
among 3 African cities in the Beta+ category, Port Louis in Mauritius achieves Betastatus, followed by South Africa's Durban at Gamma+, Dar es Salaam (Tanzania), Lusaka (Zambia), Harare (Zimbabwe), and Luanda (Angola) all at level Gamma, and Maputo (Mozambique) and Gaborone (Botswana) at level Gamma-. Pretoria (South Africa), and Windhoek (Namibia)'s global connectivity rate as being of 'high sufficiency', followed by Port Elizabeth (South Africa), Blantyre (Malawi), Antananarivo (Madagascar) and Kinshasa (DRC), all of which rate as being 'sufficiently' globally connected. While this is but one of several alternative available rankings of global city status and while the usefulness or real meaning of such rankings can be debated, their presence on this list mean that these cities (and, arguably, a handful of others in the SADC region) are clearly globally economically active.

A closer look at these cities reveal only Johannesburg, Cape Town, Port Louis and (to a lesser extent) Gaborone as significant global financial centres. As to commercial share-trading, with around 500 listings the Johannesburg Stock Exchange is by far the region's largest and busiest, but there are also significant (20+ listings) stock exchanges based in Gaborone, Port Louis, Windhoek, Victoria (Seychelles), Dar es Salaam and Harare. Johannesburg (gold), Luanda (oil) ${ }^{32}$ and Gaborone (diamonds) ${ }^{33}$ are the region's main commodity hubs.

Johannesburg and Kinshasa are by some margin the region's largest cities, and are both at the centre of so-called 'city-regions', multi-city agglomerations that are increasingly associated with global economic dominance. Johannesburg is at the core of South Africa's so-called 'Gauteng City Region' (GCR), comprising also of Pretoria and a several smaller industrial cities. As a single conglomeration, the GCR is the largest GDP producer on the African continent. Interestingly, Kinshasa, located on the banks of the Congo river in the DRC, is economically intertwined with the major city of Brazzaville, capital of a different country (Congo, not a member of the SADC) and situated on the river Congo's direct opposite bank, making it one of the world's few truly multi-national urban economic centres. Apart from Kinshasa/Brazzaville and the GCR, 8 further metropolitan areas (around the cities of Luanda, Dar es Salaam, Cape Town, Durban, Maputo, Antananarivo, Lusaka and

\footnotetext{
${ }^{32}$ See Paul Jenkins, Paul Robson \& Allan Cain 'Luanda city profile' (2002) 19(2) Cities 139 at 144145.

${ }^{33}$ See Anthony Kent \& Horatius Ikgopoleng 'Gaborone city profile' (2011) 28 Cities 478 at 478-479; Savage et al op cit note 19 at 2 .
} 
Harare) boast populations in excess of 2 million. All but the latter three of these are port cities, underlining the continued economic importance of ports as logistic trade hubs. $^{34}$

Logistically, the GCR has the SADC region's busiest airport, followed by airports in Cape Town, Durban, Port Louis and Dar es Salaam. Linked to this, Cape Town by far has the region's largest tourist market, with only Port Louis, Durban, Stone Town in Zanzibar (Tanzania, within ferry-trip distance of Dar Es Salaam) and, increasingly, Johannesburg, being able to realistically refer to themselves as international tourist destinations. ${ }^{35}$ Back to goods-trade and logistics, Durban boasts the only container port in the region ranking in the world's top $50,{ }^{36}$ but there is also significant port activity in Cape Town, Port Elizabeth, Walvis Bay (home of the mooted 'SADC port' currently under development) ${ }^{37}$, Maputo, Dar es Salaam, Richards Bay (South Africa), Beira (Mozambique), Saldanah Bay (South Africa) and East London (South Africa).

Predictably mirroring the picture at national level, South Africa's major cities are by far SADC's dominant commercial powerhouses. Unsurprisingly, they also, for the most part and for the time being, boast superior physical, digital and commercial infrastructure (arguably matched only by Port Louis in Mauritius, though in recent years cities like Luanda, Maputo and Gaborone have rapidly been closing in). A recent World Bank report has pinpointed poor infrastructure and the often fractured, physically overcrowded and disconnected urban form of African cities as main impediments to their economic performance. ${ }^{38}$ While all the major South African cities also struggle with these issues, and in particular with the physical legacy of Apartheid city planning and development policies, which have rendered them

\footnotetext{
${ }^{34}$ On the global economic significance of harbour cities see Sassen op cit note 1 at 33 .

${ }^{35}$ On South African cities' attempts to capture tourist markets, see Lemanski op cit note 6 at 451-452; Christian M Rogerson 'Urban tourism and regional tourists: Shopping in Johannesburg, South Africa' (2011) 012(3) Tijdscrift voor Economische en Sociale Geografie 316 at 321-323.

${ }^{36}$ On Durban's port as significant feature of its global economic status, see Houghton op cit note 15 at 76-77.

${ }^{37}$ The Walvis Bay port development explicitly aims at competing with Durban for the SADC region's container traffic. See Savage et al op cit note 19 at 2-5.

${ }^{38}$ Somik Vinay Lall, J Vernon Henderson \& Anthony J Venables Africa's Cities: Opening Doors to the World (World Bank Group, 2017). According to the report, African cities' main economic drawbacks are, first, that they are physically crowded without being economically dense, secondly, that they are disconnected and fragmented, and, thirdly, that they are costly for both households and firms. Ibid 10, $16,26,28,36$. Together, these factors are found to prevent economic agglomeration as well as socioeconomic prosperity for residents. See also Cem Karayalcin \& Hakan Yilmazkuday 'Trade and cities' (2014) 29(3) World Bank Economic Review 523 at 535-526; 529; 543; Njoh op cit note 10 at 25-28.
} 
spatially impractical, inefficient and unjust, $^{39}$ they typically remain comparatively better connected and better serviced than their SADC peers. Moreover, they tend to reflect a more even distribution of economic activity across their geographic areas, ${ }^{40}$ more diversified economies ${ }^{41}$ and greater population diversity, ${ }^{42}$ all of which add to their competitive advantage.

Johannesburg, in particular, boasts a remarkably diverse population ${ }^{43}$ alongside its varied and sophisticated physical, electronic and digital infrastructure, the mix of which have enabled and sustained a sufficient agglomeration of economic activities to permit meaningful global economic participation. ${ }^{44}$ The upshot (and, concomitantly, the downside for many of SADC's other cities) is that Johannesburg exercises a disproportionate pull over skills, labour, firms and investment in the region, with its allure having a significant brain-drain effect on other cities. ${ }^{45}$ But this pull is not excusive or always overpowering - most of the cities mentioned here host universities and other tertiary knowledge centres as well as high-end commercial activity, and thus both produce and require skilled labour and engage in the knowledge economy. Accordingly, there are constant cross-city (and cross-border) flows of both skilled and unskilled labour across the region, with research predictably showing that both skilled and unskilled migrants in the region prefer to stay in, or move to, cities that offer good job opportunities, but also high quality of life, a broad array of available consumer goods and services, safety, tolerance, diversity and vibrancy, and extensive expat networks. ${ }^{46}$

Overall, it is clear that, as far as formal trade and economic activity is

\footnotetext{
${ }^{39}$ See for instance City of Johannesburg Joburg Growth and Development Strategy 2040 (2011) at 73-74; Karina Landman 'A home close to opportunities in South Africa: Top down vision or bottom up demand?' (2010) 56 Town \& Regional Planning 8 at 9; Lemanski op cit note 6 at 455-456; Pillay op cit note 5 at 352. On the origins of this, see RJ Davies 'The spatial formation of the South African city' (1981) sup2 GeoJournal 59-72.

${ }^{40}$ On multinodalness and geographical spread of economic activity across a city as competitive advantages, see Jean Cavailhes, Carl Gaigne, Takatoshi Tabuchi \& Jacques-Francois Thisse 'Trade and the structure of cities' (2007) 62 Journal of Urban Economics 383-404.

${ }^{41}$ The World Bank report notes that many African cities remain locked into producing only nontradeable goods and services, often linked to the fact that their local economies remain dominated by natural resource exports. Lall, Henderson \& Venables op cit note 38 at 12; 14; 110-111.

${ }^{42}$ On the importance of human diversity for cities' performance see Barber op cit note 1 at 70 .

${ }^{43}$ For instance, Johannesburg is the only city in the region with more than 100000 foreign-born residents (coming from both high- and low-skilled groups). Sassen op cit note 1 at 86-87.

${ }^{44}$ See Onyebueke op cit note 2 at 7; Pillay op cit note 5 at 353-355; van der Merwe op cit note 5 at 40.

${ }^{45}$ See Kent \& lkgopoleng op cit note 33 at 484.

${ }^{46}$ See Collins op cit note 3 at 76 ; Malecki op cit note 2 at 642 ; Rogerson op cit note 35 at 326 ; Daniel Tevera 'Remaking life in transnational urban space: Zimbabwean migrant teachers in Manzini, Swaziland' (2014) 2 Migracijske i Etnicke Teme 155-170; Turok op cit note 2 at 1074-1075.
} 
concerned, SADC is far from an economic desert, and that its regional future economic prospects are very much tied in with the futures of its cities. The brief overview provided here has shown that there are many urban centres boasting diverse economic activity across the region, but that the potential of all of these remain hampered by infrastructural deficiencies, inefficient and fragmented urban forms, poor intra- and inter-city connections and insufficient economic diversity.

\section{Informal Trade In AND AmONG the Cities OF SADC}

Of course, formal trade presents but a small part of the picture. The informal economy in almost all of the SADC cities is huge, in some cases and in some respects eclipsing formal economic activity. ${ }^{47}$ Economic 'informalization' in the region is often viewed as a symptom of economic downturn, ${ }^{48}$ as in the Zimbabwean cities of Harare and Bulawayo, where the near-complete collapse of the formal Zimbabwean economy has meant that the preponderance of commercial and financial transactions now take place informally in makeshift street markets. ${ }^{49}$ But while this may be so, the links between formal and informal economic activity, and between different kinds of informal economic activity, are multiple and complex, and it is not possible to understand trade between cities in SADC without also paying attention to the significant cross-border and entrepreneurial (rather than localised, or purely survivalist) dimensions of informal urban markets.

Street traders are a common sight in African cities, including those in the SADC. Primarily survivalist in their orientation, street traders sell a variety of goods (such as fresh fruit and vegetables, other foodstuffs, craft items, second-hand clothing, trinkets) and provide a range of services (hairdressing, clothes mending, shoe repair and so forth), mostly (but by no means exclusively) to the urban poor. Those selling foodstuffs have supply links with local fresh produce markets and with outlying peri-urban and rural agricultural markets, and they play an important, if

\footnotetext{
${ }^{47}$ See Sally Ann Peberdy 'Border crossings: Small entrepreneurs and cross-border trade between South Africa and Mozambique' (2000) 91(4) Tijdscrift voor Economische en Sociale Geografie 361 at 362; Peberdy \& Crush op cit note 19 at 116; Sally Peberdy \& Christian Rogerson 'Transnationalism and non-South African entrepreneurs in South Africa's small, medium and micro-enterprise (SMME) economy' (2000) 34(1) Canadian Journal of African Studies 20 at 35.

${ }^{48}$ See Pillay op cit note 5 at 345-346.

${ }^{49}$ See Norimitsu Onishi \& Jeffrey Moyo 'Trade om the streets, and off the books, keeps Zimbabwe afloat' New York Times (4 March 2017); Christian M Rogerson 'Responding to informality in urban Africa: Street trading in Harare, Zimbabwe' (2016) 27(3) Urban Forum 229 at 237-238.
} 
poorly studied and under-appreciated, role in maintaining urban food security in the region. ${ }^{50}$

Due to its mostly localised nature, survivalist street trade is of limited interest for present purposes. ${ }^{51}$ However, it constitutes a cog in an intricate wheel of international trade networks, which typically operate below the radar of trade scholars and authorities. Thousands of cross-border traders operate small businesses (with not insignificant turnovers and numbers of employees) across SADC, importing and exporting a large variety of goods, often across several countries. $^{52}$

In this subsection, I discuss the trade networks associated with so-called 'cross-border shopping' in the city of Johannesburg which, mirroring its role as the formal international trade giant of the SADC, is also arguably the dominant hub of informal international retail trade in the region. ${ }^{53}$ But trade in retail products is by no means the only, or even predominant, cross-border flow of goods between cities (and surrounding rural areas) in SADC. Other international informal trade networks in the region include, for instance, trade in fresh seafood caught in the waters outside Maputo and supplied to restaurants in Johannesburg, ${ }^{54}$ Durban and other South African cities; trade in handmade ornaments and curios manufactured across SADC and sold in tourist markets in Durban and Cape Town; ${ }^{55}$ trade in second-hand clothes supplied to informal markets or formal stores across the region, ${ }^{56}$ and trade in fabric manufactured in Maputo, Dar es Salaam and West African cities, and sold to both formal and informal retail outlets in almost all major SADC cities. ${ }^{57}$ Moreover, research into cross-border trade between Malawi and its neighbouring countries has shown that most formal international trade markets in SADC (around goods such as sugar, fertilizer, beer, coffee and tobacco) also have informal 'shadow markets'

\footnotetext{
${ }^{50}$ See IJ Minde \& TO Nakhumwa 'Unrecorded cross-border trade between Malawi and neighboring countries' Office of Sustainable Development Bureau for Africa Technical Paper no 90 (1998) at 5; 43; Onishi \& Moyo op cit note 49.

${ }^{51}$ For economic analysis of survivalist street trade in South African cities, see for instance Marlese von Broembsen 'Informal business and poverty in South Africa: Re-thinking the paradigm' (2010) 14 Law, Democracy \& Development 1-34.

${ }^{52}$ On the size of these businesses, their turnovers, their number of employees and outlet locations and so forth, see for instance Minde \& Nakhumwa op cit note 50 at 31; 44; Peberdy op cit note 47 at 369; 373; Peberdy \& Rogerson op cit note 47 at 28; 34-36.

${ }^{53}$ See Rogerson op cit note 35 at 324; Tanya Zack et al Cross Border Shopping in Johannesburg's Inner City Research Report Commissioned by the Johannesburg Inner City Partnership (2017) at 7.

${ }^{54}$ See Peberdy op cit note 24 at 118; Peberdy op cit note 47 at 360-361.

${ }_{55}^{5}$ See Peberdy op cit note 24 at 208-209; 212-214; Rogerson op cit note 35 at 324.

${ }^{56}$ See Minde \& Nakhumwa op cit note 50 at 35-36; Peberdy op cit note 47 at 367-369.

${ }^{57}$ See Peberdy op cit note 24 at 208; Pebery \& Rogerson op cit note 47 at 28.
} 
flowing along similar routes, and constituting a significant portion of the actual movement of the traded goods across borders. ${ }^{58}$

Thousands of traders from across SADC go on 'shopping trips' to the inner city of Johannesburg, sometimes jokingly referred to as the 'Dubai of Africa' ${ }^{59}$ where they buy goods, both on order for customers in other (often more than one) SADC countries and for resale in both formal retail outlets and informal street markets in other SADC cities. A recent research report commissioned by the Johannesburg Inner City Partnership and conducted in Jeppe - a particular small-scale retail-heavy sub-area of the Johannesburg CBD - interviewed 'cross-border shoppers' from Zambia, Malawi, Lesotho, Botswana, Zimbabwe, Namibia, Mozambique, the DRC, Swaziland and Cameroon, indicating the truly international character of this trade, which is said to contribute billions of rands to Johannesburg's annual formal retail turnover and to contribute significantly to its status as the SADC region's mostglobalised city. ${ }^{60}$

Goods traded in this manner include all forms of homeware, furniture, foodstuffs, large and small kitchen appliances, tools, electronics (cell-phones and accessories, television or audio equipment), new and second-hand clothing and shoes, medicine, cosmetics, car parts, liquor, luggage, hardware, sporting goods, computer software and books. ${ }^{61}$ These are procured from and resold to both formal (wholesale and retail), semi-formal and street-level informal businesses. ${ }^{62}$

In Johannesburg, the extensive urban supply chains for this massive retail market extend far beyond SADC - 'trade in this sector is truly globalised in terms of traders, retailers, customers and goods flowing across African and continental borders' ${ }^{63}$ In particular, there are mass imports of Chinese goods (homeware and clothing mostly sourced in Guangzhou, and electronic products mostly sourced from informal traders in Hong Kong's infamous Chunking Mansions) which are resold in Chinese-operated wholesale malls across the city. These 'China Malls' also have extensive retail links with Ethiopian traders operating hundreds of small shops (also selling Ethiopian coffee, fabric and other imports) in the inner-city area of 'Jeppe',

\footnotetext{
${ }^{58}$ See generally Minde \& Nakhumwa op cit note 50 .

59 See Zack et al op cit note 53 at 129.

60 Zack et al op cit note 53, specifically 6-7; 100; 129. See also Rogerson op cit note 35 at 319.

${ }^{61}$ See Peberdy op cit note 24 at 209; Peberdy op cit note 47 at 367-369; Peberdy \& Rogerson op cit note 47 at 31; Rogerson op cit note 35 at 324; Zack et al op cit note 53 at 110.

62 See Peberdy op cit note 47 at 364; 367; 374; Peberdy op cit note 24 at 211.

63 Zack et al op cit note 53 at 6.
} 
which is located close to major cross-border transit hubs and therefore a preferred shopping spot. Also significant is significant networks of clothing, luggage, homeware and fabric imports from India, Bangladesh and Pakistan, sold at the nearby Oriental Plaza in Fordsburg on the CBD's outskirts. ${ }^{64}$ 'Shoppers' are also sometimes suppliers, bringing goods (Mozambican fabric, Malawian liquor) from their home towns for sale to their Johannesburg-based contacts. ${ }^{65}$

While significant portions of the trade described here are above-board and take place in the city's formal retail sector, equally significant portions are below the radar and illicit, involving counterfeit goods and the flouting of customs and financial regulations, zoning and associated spatial bylaws, and migration laws. ${ }^{66}$ Overall, apart from representing an international trade network in and of itself, the crossborder shopping 'trade' in Johannesburg also involves and depends upon (both legal and illicit) cross-border flows of traders, labour, money and information, thereby concretely bearing out Sassen's assertion that globalisation produces not only highend international financial and business flows, but also extensive and intricate lowend flows of goods, capital and labour. ${ }^{67}$ Importantly, studies of cross-border shopping in Johannesburg reveal the poorly understood linkages between these high-end and low-end flows, as well as between different sectors of the economy and between formal and informal, legal and illegal trade.

Indeed, cities across the SADC region are increasingly competing for informal retail trade and low-end flows much as they do for formal trade and 'global city' accolades -shopping malls in Gaborone, Lusaka and Maputo as well as a similarly multinational informal/formal sector agglomeration in Durban increasingly provide competition and lure cross-border shoppers away from Johannesburg's inner city, ${ }^{68}$ and there are reports of formal South African retail as well as informal Ethiopian and Somali-run outlets relocating to the northern South African town of Musina in order to

\footnotetext{
${ }^{64}$ On these various international supply chains and their different retail outlets across the city, see Richard Grant \& Daniel Thompson 'City on edge: Immigrant businesses and the right to urban space in inner-city Johannesburg' (2015) 36(2) Urban Geography 181 at 188-189; Peberdy op cit note 24 at 211; Daniel K Thompson \& Richard Grant 'Enclaves on edge: Strategy and tactics in immigrant business spaces of Johannesburg' (2015) 26 Urban Forum 243 at 255-56; Tanya Zack 'Jeppe where low-end globalisation, ethnic entrepreneurialism and the arrival city meet' (2015) 26 Urban Forum 131 at $135-137 ; 139 ; 142$; Zack et al op cit note 53 at $7 ; 12-13$.

${ }^{65}$ See Peberdy op cit note 47 at $370-371$.

${ }^{66}$ See Zack op cit note 64 at 135-136; 139; 147; Zack et al op cit note 53 at 15.

${ }^{67}$ See Sassen op cit note 1 at 86-89; also Zack op cit note 64 at 135-136.

${ }^{68}$ See Rogerson op cit note 35 at 323; 326.
} 
capture the Zimbabwean cross-border shopping market. $^{69}$

Of further interest for purposes of this working paper, research among informal cross-border traders in the region and of competition between cities for informal trade show not only how barriers to formal trade create and feed informal trade networks, ${ }^{70}$ but also reveal the similar effects of non-tariff related barriers to trade on both the formal and informal sectors. As with formal trade, the cross-border shopping trade is typically inhibited by convoluted customs processes, regulations on customs duties and value-added tax, banking and financial sector regulations, roadtolls and visa costs, ${ }^{71}$ by corruption at various points along supply chains and trade networks, ${ }^{72}$ by high transport costs, ${ }^{73}$ by poor transport-, storage- and related infrastructure, ${ }^{74}$ and by the spatial fragmentation and poor urban environment in many of the cities of SADC. ${ }^{75}$

\section{Urban Governance, Urban Agency and InTERcity Trade}

Thus far, this working paper has illustrated the extent of formal and informal trade in the cities of SADC and have linked this with cities' 'global' status and their pivotal role in national economies. It has further touched upon features of the urban landscape, such as disconnectedness, fragmentation, congestion and lack of safety, that impact negatively on intra- and inter-urban (formal and informal) commerce in the region.

The way in which cities are governed obviously impacts on these and related

\footnotetext{
${ }^{69}$ See Zack et al op cit note 53 at $7 ; 59$.

${ }^{70}$ See Minde \& Nakhumwa op cit note 50 at 42.

${ }^{71}$ See Peberdy op cit note 24 at 215-217; Peberdy op cit note 47 at 369; Peberdy \& Crush op cit note 19 at $116 ; 120 ; 122$.

${ }^{72}$ See Peberdy op cit note 24 at 216-217; Peberdy op cit note 47 at 373; Peberdy \& Crush op cit note 19 at 121 (regarding bribery and extortion by customs and migration officials); Thompson \& Grant op cit note 64 at 252; 256; Zack op cit note 64 at 144; Zack et al op cit note 53 at 62; 85; 91 (re corruption and bribery by Johannesburg's metropolitan police).

${ }^{73}$ Participants in several studies site high transport costs as a reason why they do not make more cross-border shopping trips in a given year. See Peberdy op cit note 24 at 211.

${ }^{74}$ See Rogerson op cit note 35 at 324-326. For example, Peberdy \& Crush op cit note 19 at 122 report how Mozambican cross-border traders have bemoaned the cancellation of passenger train services between Maputo and Durban, which meant that traders from Maputo could now only reach Durban via Swaziland, which added another layer of customs and border-processes to their trade endeavours.

${ }^{75}$ Cross-border shoppers in Johannesburg, for instance, complain of a lack of affordable and welllocated accommodation options, difficulties reaching wholesale outlets in different parts of the city, lack of public bathrooms, xenophobia and safety concerns. See Robertson op cit note 35 at 324-326; Zack et al op cit note 53 at $7 ; 76 ; 98 ; 124 ; 129 ; 132-133 ; 140$.
} 
features of the urban commercial landscape. Urban local governments need both the power, the political will and the resources to address the problems that hamper cities' economic performance. Indeed, the economic woes of some of the cities in the SADC region are not uncommonly attributed, at least partly, to weak governance. ${ }^{76}$ Research in first world cities has further shown that the ways in which cities wield 'conventional' local government powers, such as the ways in which they exercise discretion around zoning, building permissions, municipal rates, service schedules and local development tax incentives, may have a determinative impact on international trade and, ultimately, on cities' ability to meaningfully compete in global markets. ${ }^{77}$

Over and above this, it is increasingly clear that success in global markets hinges on cities' active, even aggressive, pursuit of economic goals, status and accolades. As alluded to above, cities actively compete for the economic spoils of globalization, and there is some unease about the ways in which developing world cities are at once hampered in this competition and side-lined for their failure to fully take part. More significantly, it is typically feared that orienting themselves towards global economic competitiveness may cause developing-world cities to take their eye off of the far more urgent ball of ensuring the socio-economic well-being of their residents.

Be this as it may, withdrawing from the global economy is not an option for the cities of SADC and it is imperative that they are both equipped and geared towards economic success, while simultaneously remaining committed, in the first instance, to their socio-economic and developmental mandates. ${ }^{78}$ In this subsection, I begin to explore the cities of SADC's trade related orientation, as well as the extent of their formal commercial powers, competencies and agency.

Both the SADC and the national governments in the region have realised the importance of the region's cities for its economic prospects. As alluded to above, some impressive cross-border infrastructure projects aimed at economic development have materialised in the region, and national governments are increasingly expending effort on boosting the economic strengths and capacities of their cities. But these efforts often conceptualise of local government only as

\footnotetext{
${ }^{76}$ See Jenkins, Robson \& Cain op cit note 32 at 144-145; Malecki op cit note 2 at 641.

${ }^{77}$ Schragger op cit note 2, generally. See also Lall, Henderson \& Venables op cit note 38 at 28 ; Turok op cit note 2 at 1071 .

${ }^{78}$ See Houghton op cit note 15 at 75-76; Parnell \& Robinson op cit note 9 at 338-339; 348.
} 
implementing and/or enabling agent, ${ }^{79}$ whereas growing international evidence seems to suggest that truly economically successful cities are taking the wheel themselves when it comes to maximising their economic potential.

For this reason, among others, commentators and economic development agencies increasingly emphasised the importance of the decentralisation of government functions, and the concomitant democratization of local government, as imperative for urban economic development. ${ }^{80}$ Across SADC, national governments have, on paper, bought into this and have almost universally committed to the decentralisation of state power so as to enable (especially urban) local government to fulfil a more primary developmental role, often to the point of passing constitutional amendments or new legislation that dramatically increase the powers, resource base and functions of local government (with urban local government often occupying a special position in domestic governance hierarchies). ${ }^{81}$ But in practice, following through on this undertaking has been slow and uneven, hampered both by national government unwillingness to relinquish power (especially in the ever-increasing number of instances where the democratization of local government has been followed by elected local government being dominated by opposition political parties $^{82}$ ) and by debilitating lack of capacity at local government. ${ }^{83}$ Accordingly, decentralisation across SADC remains either a paper tiger or woefully incomplete.

Perhaps predictably, the most powerful, financially secure and autonomous local governments in the region are those at the helm of the major South African cities, which are democratically elected and function under an explicit, constitutionally stipulated, developmental mandate. ${ }^{84}$ South African cities enjoy

\footnotetext{
${ }^{79}$ See remarks by Collins op cit note 3 at 77-78; Pillay op cit note 5 at 345 .

${ }^{80}$ See Parnell \& Robinson op cit note 9 at 339-40; Purshottama Reddy \& John-Mary Kauzya 'Local government capacity in the Southern African Development Region (SADC)' (2015) 14(3) Public Policy and Administration 200 at 207; David Simon 'Windhoek city profile' (1995) 12(3) Cities 139 at 146; Van Vliet op cit note 2 at $37-38$.

${ }^{81}$ See Pillay op cit note 5 at 348; Reddy \& Kauzya op cit note 80 at 207-216.

82 On the phenomenon of opposition party-led cities in sub-Sharan Africa (which includes city governments in the SADC cities of Harare, Bulawayo, Gaborone, Cape Town, Johannesburg, Pretoria and Port Elizabeth) as source of significant intergovernmental tension which sometimes bedevils urban progress, see for instance Claire Benit-Gbaffou, Alain Dubresson, Laurent Fourchard, Karine Ginisty, Sylvy Jaglin, Ayodeji Olukoju, Sam Owuor \& Jeanne Vivet 'Exploring the role of party politics in the governance of African cities' in Simon Bekker \& Laurent Fouchard (eds) Governing Cities in Africa, (HSRCPress, 2013) 17-42.

${ }^{83}$ See, for instance, generally Reddy \& Kauzya op cit note 80; Simon op cit note 80 at 144.

84 Section 152(1) of the South African Constitution (1996) determines that the objectives of local government include 'to provide democratic and accountable government for local communities' and 'to promote social and economic development'.
} 
constitutionally entrenched powers and functions to administer, make bylaws for and exercise executive authority over a large number of functional areas (including, importantly, 'municipal planning', 'trading regulations', 'markets' and 'street trading'), ${ }^{85}$ a constitutional entitlement to have other functions which can be exercised more effectively by local government legislatively delegated to them, ${ }^{86} \mathrm{a}$ constitutionally entrenched funding base ${ }^{87}$ (which has ensured that the South African cities discussed in this working paper are all, for the most part, financially selfsustainable) as well as elevated financial and functional competencies in terms of national municipal legislation (which distinguishes between metropolitan municipalities with enhanced autonomy, on the one hand, and regional and district municipalities on the other). ${ }^{88}$ They are accordingly well equipped to act autonomously in pursuit of economic development. ${ }^{89}$ Yet, even South African metropolitan councils have fallen victim to intergovernmental tugs-of-war and have sometimes been forced along developmental trajectories which they themselves would not have chosen. ${ }^{90}$ Moreover, lack of capacity outside of the major metropolitan areas have precluded secondary South African cities from effectively fulfilling their developmental mandate. ${ }^{91}$

Elsewhere in the SADC region, the position is less favourable. A detailed comparative study of the constitutional and legislative developmental powers of urban local government in the region is still to be undertaken as part of this research, but a preliminary literature review suggests that actual and effectively implemented region-wide decentralization is still very much an aspiration. ${ }^{92}$ Accordingly, when it

\footnotetext{
${ }^{85}$ Section156(1) and (2) read with Schedules 4B and 5B of the South African Constitution (1996).

${ }^{86}$ Section 156(4) of the South African Constitution (1996).

${ }^{87}$ See sections 228 and 230 A of the South African Constitution (1996).

${ }^{88}$ See section 155(1) of the 1996 South African read with section 2 of the Municipal Structures Act 117 of 1998.

${ }^{89}$ See Pillay op cit note 5 at 351-352. I have discussed the constitutional powers and functions of South African urban local governments, in the specific context of autonomous urban governmental action, in detail in Marius Pieterse 'A Year of Living Dangerously? Urban Assertiveness, Cooperative Governance and the First Year of Three Coalition-Led Metropolitan Municipalities in South Africa' (forthcoming 2018). For a more comprehensive overview, see Jaap De Visser Developmental Local Government: A Case Study of South Africa (Intersentia, 2005).

${ }^{90}$ See Glen Robbins 'The Dube trading port - King Shaka international airport mega-project: Exploring impacts in the context of multi-scalar governance processes' (2015) 45 Habitat International 196-204 (detailing how the eThekwini Metropolitan Council in the city of Durban was strung along, against its will, to support, service and enable major developmental projects that it regarded as financially unsustainable and in contravention of its own developmental objectives).

${ }^{91}$ See Reddy \& Kauzya op cit note 80 at 207-208.

92 See Charles Manga Fombad 'Internationalization of constitutional law and constitutionalism in Africa' (2012) 60(2) American Journal of Comparative Law 439-473; Jenkins, Robson \& Cain op cit
} 
comes to formal trade and economic interactions, city leadership across SADC mostly finds itself in the position of kowtowing national developmental visions, meaning that, whatever their intentions may be, their ability to autonomously navigate the global economy remains limited.

Intention-wise, it is probably not coincidental that the big South African cities appear to be the ones in the region that are the most aware of their economic role, and that are most keen to autonomously pursue 'global city' status and attendant (formal) local economic development. While a recent article detailing the rise of cities as international economic actors observed that over a third of the members of the World Association of Investment Promotion Agencies are local-government or regionally based, ${ }^{93}$ in the SADC only Durban, the Gauteng Region and Pretoria are members, whereas all other SADC member states are represented by national economic development agencies. ${ }^{94}$ Apart from all South African cities being legislatively mandated to adopt Integrated Development Plans, and these often revealing a unique urban economic vision, Johannesburg, Durban and Cape Town further boast institutionalised, cooperative local government / private sector fora which explicitly concern themselves with the cities' economic growth. Between them, the Durban Growth Coalition, Johannesburg Development Agency, Johannesburg Inner City Partnership and the Cape Town Partnership, have spurred, overseen or participated in the majority of major urban infrastructure projects in the country, as well as in its most significant inner-city regeneration drives. ${ }^{95}$

But other city governments across the SADC region are also showing signs of growing economic self-awareness and ambition. Even the smaller and less connected cities in the region are adopting development plans or similar economic strategic documents, ${ }^{96}$ and there have even been instances of inter-city collaboration in this regard, such as a successful 'mentoring partnership' between Johannesburg and Lilongwe around the adoption of an Integrated Development Programme for the

note 32 at 147; Reddy \& Kauzya op cit note 80 200-224; Carlos Nunes Silva 'Local government and urban governance in Lusophone African countries: From colonial centralism to post-colonial slow decentralization' in Silva (ed) op cit note 21, 13-72.

${ }^{93}$ Tavares-Lehmann \& Tavares op cit note 2 at 1.

${ }^{94}$ See http://www.waipa.org/members-list/.

${ }^{95}$ For discussion of these partnerships and initiatives, see Houghton op cit note 15 at 81-86 (re Durban); Lemanski op cit note 6 at 451-453 (re Cape Town); Pillay op cit note 5 at 353-360 (re Johannesburg).

${ }_{96}$ See, for example, Marais et al op cit note 29 (re articulating an economic vision for Bloemfontein in relation to global economic environment); Sihlongonyane op cit note 29 at 256-260 (regarding adoption of Manzini's first economic strategic plan). 
latter. ${ }^{97} \mathrm{~A}$ further indication is that twin/sister city agreements in the region (both between cities in SADC and with cities elsewhere in the developed and developing world) are increasing and, in keeping with global trends, are increasingly reflecting economic cooperation initiatives. ${ }^{98}$

Interestingly, while this discussion shows that their power to drive and enhance formal trade in their jurisdictions is on average quite limited, and that their willingness to conduct themselves as economic entities in their own right is only just emerging, almost all the cities in SADC have significant regulatory powers over informal trade and have managed the informal economic sectors in their jurisdictions for years. Yet, the content and implementation of local government bylaws and regulations governing street trade in SADC cities reveal a disappointing lack of awareness of the economic importance and dynamics of informal trade, and a lack of distinction between survivalist street trade, informal cross-border trade and other informal flows of goods, capital and labour. ${ }^{99}$ Most cities in SADC's street trading bylaws are inherited from colonial regimes and continue to reflect a bias against street trade, which cities tend to attempt to control, minimise or eradicate, rather than to support or enable. ${ }^{100}$ Even cities like Durban and Johannesburg, which have adopted progressive and enabling street trading bylaws and policies, implement these restrictively and haphazardly. ${ }^{101}$

\footnotetext{
${ }^{97}$ See United Cities and Local Government Mentoring Story: Lilongwe \& Johannesburg Experience 2008-2012 available at

https://www.learning.uclg.org/sites/default/files/documents/04_mentoring_story-_johannesburg_lilongwe_eng.pdf. ${ }_{98}$ On global trends in this regard see Rolf $D$ Cremer, Anne De Bruin \& Ann Dupuis 'International sister-cities: Bridging the global-local divide' (2001) 60(1) American Journal of Economics and Sociology 377-401; Van Vliet op cit note 2 at 37. A casual internet search for twinned cities within SADC revealed the following partnerships: Cape Town/Luanda; Cape Town/Maputo; Durban/Bulawayo; Durban/Maputo; Johannesburg/Kinshasa; Johannesburg/Matola; Johannesburg/WIndhoek; Polokwane/Bulawyo; Brazzaville/Kinshasa; Brazzaville/Johannesburg; Ndola/Walvis Bay; Ndola/Blantyre; Mutare/East London; Gaberone/Thabazimbi. See

https://ipfs.io/ipfs/QmXoypizjW3WknFiJnKLwHCnL72vedxjQkDDP1mXWo6uco/wiki/List_of_twin_tow ns_and_sister_cities_in_Africa.html

${ }_{99}$ See Caroline Skinner 'Getting institutions right? Local government and street traders in four South African cities' (2000) 11(1) Urban Forum 49 at 51; Zack op cit note 64 at 147; Zack et al op cit note 53 at 7 .

100 See Antonio Pezzano "Integration" or "selective incorporation? The modes of governance in informal trading policy in the inner city of Johannesburg' (2016) 52(4) Journal of Development Studies 498 at 499; Marius Pieterse 'Rights, regulation and bureaucratic impact: The impact of human rights litigation on the regulation of informal trade in Johannesburg' (2017) 20(1) Potchefstroom Electronic Law Journal 1 at 5-7; Rogerson op cit note 49 at 230-345; EJ van Rooyen \& LP Malan 'Informal trading in the city of Johannesburg: Suggestions to create an enabling environment' (2007) 42(7) Journal of Public Administration 707-720.

${ }_{101}$ See Pezzano op cit note 100 at 500-507; Pieterse op cit note 100 at 6; Skinner op cit note 99 at 53-58; Caroline Skinner 'The struggle for the streets: Processes of exclusion and inclusion of street traders in Durban, South Africa' (2008) 25(2) Development Southern Africa 227-242; Thompson \&
} 
The studies among informal cross-border retail traders in Johannesburg discussed in the previous subsection reveal that urban local authorities often have both the power and capacity to address many of the factors (poor street trade infrastructure, police harassment and corruption, lack of storage facilities, poor intercity transport and so forth) that inhibit informal international trade in the city. Moreover, the links between formal and informal sectors in the city, emerging from these studies, mean that addressing these factors would also go a long way towards addressing socio-spatial barriers to formal trade. Enabling informal trade, limiting its potential hazardous side-effects, ensuring its harmonious coexistence with formal business in the city, and focusing on creating a physical urban environment conducive to both formal and informal business, seems to be an obvious way in which developing-world city governments can simultaneously advance their global economic competitiveness and contribute to the socio-economic development of their residents. ${ }^{102}$

In this respect, Johannesburg's recent demonstrated awareness of the importance of informal cross-border trade for its economy and global status (demonstrated through its commissioning of research ${ }^{103}$ aimed at enhancing its attractiveness to informal 'cross-border shoppers') perhaps represents a welcome about-turn from its previous, compartmentalized and incongruent regulation of the intersections between its formal and informal economic sectors.

\section{Reflections}

Cities are the physical sites of most economic activity. Therefore, the ways in which they function, and are governed, matter economically. While trade and economics are generally regarded as being mostly of national concern, ' $[\mathrm{t}] \mathrm{h}$ he city is the more relevant scale for thinking about the constitutional rules that govern the interjurisdictional mobility of persons, goods and capital'. ${ }^{104}$

In the SADC, too, trade and commerce are both constitutive of, and highly dependent on, cities. Moreover, people in the SADC region have always been highly

\footnotetext{
Grant op cit note 64 at 244.

${ }^{102}$ See Skinner op cit note 99 at 60-61; Zack op cit note 64 at 147-148; Zack et al op cit note 153 at 6; $129-130$

${ }^{103}$ Zack et al op cit note 53.

${ }^{104}$ Schragger op cit note 2 at 1107.
} 
mobile and labour, goods and capital flow across borders daily, albeit often undetected by legal or governmental frameworks.

This working paper has shown that the cities of SADC are players in the global economy, and that their leadership is waking up to this fact. However, it also appears that they are somewhat lacking, both in formal powers and in the inclination and self-awareness required to meaningfully partake in the global economy while simultaneously prioritising the socio-economic upliftment of their residents.

The economic challenges faced by the cities of SADC are formidable. All bear the burden of national legacies of vast poverty and underdevelopment. All struggle with diversifying their economies, reviving fledgling manufacturing sectors and facilitating sufficient agglomeration for high-end economic activity. ${ }^{105}$ All are short of essential infrastructure, most are spatially fragmented, disconnected and unequal.

So what is required to enable the cities of SADC to move towards meeting these challenges? While this research is still in its infancy, a few tentative suggestions may be offered:

At a regional and national level, the mooted moves towards a more connected SADC region, through the establishment of a common market and a free movement zone need to be pursued more aggressively, and planned urban, intra-urban and cross-national infrastructure projects will go a long way to enhance urban connectedness and economic capacity. Commercial legal systems need to be harmonised ${ }^{106}$ and existing legal barriers to the formal and informal flows of money, goods and people across the region need to be re-evaluated. Perhaps most importantly, state power needs to be more effectively decentralised, so as to enable urban local governments to take control of their own economic destiny whilst simultaneously working towards the achievement of national development goals. ${ }^{107}$ This, of course, will only bear fruit if the capacity of urban local government is simultaneously enhanced.

City governments in the region need to wield their 'conventional' local government powers around land use, zoning, levying rates and taxes, and so forth, with developmental objectives, the improvement of urban infrastructure and the

\footnotetext{
${ }^{105}$ See Lall, Henderson \& Venables op cit note 38 at 12-14.

${ }_{106}^{106}$ See generally Shumba op cit note 20 .

${ }^{107}$ See Turok op cit note 2 at 1072.
} 
creation of a better economically functioning urban form in mind. ${ }^{108}$ Urban law frameworks at all levels must be updated, streamlined and improved. Regardless of their formal powers, city governments must think of themselves as economic and socio-political agents and conduct themselves accordingly - international experience has shown that they have tremendous soft power at their disposal and that their 'inferior' legal status may in fact lend them additional flexibilities to conduct themselves in ways that are economically beneficial to all of their residents compared to national governments, for instance, they are practically far less burdened by customs, immigration regimes, international relations protocols and so forth. ${ }^{109}$ Moreover, regardless of formal legal regimes, cities actually harbour and channel the labour, capital and goods that flow through them through the day-to-day mundanities of urban governance, and can easily do so more developmentally.

One example that emerges particularly prominently from the research canvassed in this working paper is cities in SADC's management of their informal economies. It is clear that informal trade in the region has intricate connections to the formal economy as well as strong transnational dimensions. Moreover, the informal economies of the cities in the SADC region are intricately connected, so that management of or clampdowns on informal trade in one city impact on both the formal and informal sectors of other cities in the region, in ways that remain far too poorly understood. Given that the regulation of informal economic activity is typically a local government competence and concern, there is a real opportunity for cities in SADC to leverage these connections and links in ways that boost both their formal and informal economies - '[w]hen making policy for the future, both national and local governments need to develop an understanding of transnationalism that extend beyond notions of a globalized formal economy to encompass the informal sector and immigrant small entrepreneurs'. ${ }^{110}$

Cities in SADC compete on global markets, both in the formal and informal economies. While a degree of this is inevitable, it is important to understand, first, that international competitiveness is not the be-all and end-all of economic flourishing and that urban economies can equally thrive through servicing local and

\footnotetext{
${ }^{108}$ See Lall, Henderson \& Venables op cit note 38 at 20-22; 28; 32; Schragger op cit note 2 at 1106 1108; Njoh op cit note 10 at 25-28; Turok op cit note 2 at 1071-1072.

${ }^{109}$ See Barber op cit note 1 at 163-166; Schragger op cit note 2 at 1107.

${ }^{110}$ Peberdy \& Rogerson op cit note 47 at 40.
} 
regional needs. ${ }^{111}$ More importantly, international experience of city-regions suggest that economic agglomeration is not only an intra-urban but also a regional phenomenon. ${ }^{112}$ Region-sharing cities need to co-operate as they compete (locally but also at the scale of SADC and beyond) - governmental and economic capacity across the region is best enhanced through inter-urban information sharing and collaboration, whereas there is much economic benefit to be gained from exploiting and leveraging existing cross-border urban networks and flows, encouraging the formation of networked specialization clusters ${ }^{113}$ and so forth. In this respect, the social and commercial links established by and between the cities of SADC can go further than agreements between their respective nation states. While there will always be inequalities between places, Ivan Turok reminds us that cities which share knowledge and resources 'might benefit from economies of scale and scope, and thereby gain a collective competitive advantage'. ${ }^{114}$

Overall, we would do well to remember that even the most high-levelfunctioning global cities remain places where ordinary people live everyday lives. ${ }^{115}$ It is in and from the diversity of these lives that urban economic activity grows, and it is through enabling individual capabilities that collective flourishing becomes possible. Through its sheer physical presence in and authority over the spaces in which people find themselves, local government is best placed to uplift populations, urban and otherwise. Cities in SADC should become more aware of this fact, and be empowered to act accordingly - 'cities make economic sense and can be reformed through economic policy, but in no small part because they make civic, social, cultural and political sense'. ${ }^{116}$

\footnotetext{
${ }_{111}^{11}$ See Marais et al op cit note 29 at 212-215; Turok op cit note 2 at 1072-1074.

112 See generally Sassen op cit note 8; Sassen op cit note 1.

113 Sassen op cit note 8 shows the near-organic formation of such clusters through cooperative competition in the leading cities of the global financial sector.

114 Turok op cit note 2 at 1074.

${ }_{116}^{115}$ See Barber op cit note 1 at 65-66.

${ }^{116}$ Barber op cit note 1 at 221.
} 